\title{
Ecosystem services provided by South African palmiet wetlands: A case for investment in strategic water source areas
}

\author{
Alanna J. Rebelo ${ }^{\mathrm{a}, \mathrm{b}, *}$, Courtney Morris ${ }^{\mathrm{b}}$, Patrick Meire ${ }^{\mathrm{a}}$, Karen J. Esler ${ }^{\mathrm{b}, \mathrm{c}}$

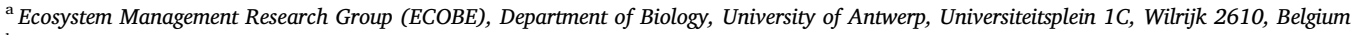 \\ ${ }^{\mathrm{b}}$ Department of Conservation Ecology and Entomology, Stellenbosch University, Private Bag X01, Matieland, 7602 Stellenbosch, South Africa \\ ${ }^{\mathrm{c}}$ Centre for Invasion Biology (C.I.B), Stellenbosch, South Africa
}

\section{A R T I C L E I N F O}

\section{Keywords:}

Flood attenuation

Water quality regulation

Carbon sequestration

Peatland

Fen

Rapid assessment and validation

Degradation

Payment for ecosystem services

\begin{abstract}
A B S T R A C T
Wetlands globally are highly threatened by agriculture, and damage associated with it, such as invasion by alien species and the impacts of fertilizers and pesticides. South African palmiet wetlands make an interesting case study to investigate this, as they are valuable valley-bottom, peat-forming systems, highly threatened by agricultural development. Currently most agriculture in these palmiet wetlands is marginal (low agricultural productivity) due to the challenges of farming a system that experiences severe floods and erodes rapidly, forming gullies, when wetland vegetation is disturbed. The current situation seems to be a lose-lose situation for nature and society. We aimed to assess this conflict between water-related services and agriculture objectively by comparing provision of fifteen ecosystem services by degraded and pristine sections of three palmiet wetlands using a rapid ecosystem service assessment tool (WET-Ecoservices). To validate this technique, we compared results to those obtained from examining three key ecosystem service complexes in slightly more detail. We found that pristine palmiet wetlands provide valuable ecosystem services to society, which are currently being compromised for private, marginal agricultural gain. These pristine wetlands sequester between 21 and 41 g.m ${ }^{-2}$ of carbon per year, have nitrogen and phosphorus uptake efficiencies of $62-85 \%$ and $16-89 \%$ respectively, and provide about 16 times more flood attenuation relative to degraded ones. The full impact of degradation on wetland ecosystem services was not entirely captured by the rapid ecosystem service assessment tool: WET-Ecoservices. We suggest some adaptations to this tool for the valley-bottom wetland hydro-geomorphic unit. Overall, these wetlands have high potential for incorporation into a Payments for Ecosystem Services scheme, due to the ecosystem services provided and their position above important municipal dams. We recommend collaboration between private landowners struggling with marginal agriculture, and decision makers in cities dealing with water shortages and debt to ensure the most efficient and judicious use of these palmiet wetland ecosystem services.
\end{abstract}

\section{Introduction}

Wetlands are fragile ecosystems, essential for human well-being, and yet threatened throughout the world (MEA, 2005). Wetlands are also valuable ecosystems as they are responsible for providing various complex ecosystem functions and services that no other ecosystems can provide (Kotze et al., 2007; Moor et al., 2017). Important ecosystem services typically provided by wetlands include water provision, water purification, water regulation, and many others, including cultural services. However, three ecosystem service complexes stand out where wetlands are concerned: water flow regulation (water storage and flood attenuation), climate regulation (energy exchange, carbon sequestration and greenhouse gas emissions) and water quality regulation (biogeochemical transformations, retention or removal of excess nutrients/pollutants from runoff) (Moor et al., 2017). Moor et al. (2017) call these 'complexes' as this illustrates the multiple aspects or components of each ecosystem service (also see Boerema et al., 2017) that may result in trade-offs or be mutually exclusive. Major threats to wetlands globally are invasive species, which result in loss of suitable habitats and biodiversity (Zedler and Kercher, 2004), as well as eutrophication as a result of increased fertilizer use. In South Africa, wetlands are in a critical state, with more than $65 \%$ threatened (Nel and Driver, 2012) and over 50\% destroyed (Cowan, 1995). This is mainly due to anthropogenic activities (Nel and Driver, 2012).

\footnotetext{
*Corresponding author at: Department of Conservation Ecology and Entomology, Stellenbosch University, Private Bag X01, Matieland, 7602 Stellenbosch, South Africa.

E-mail address: ARebelo@sun.ac.za (A.J. Rebelo).
} 


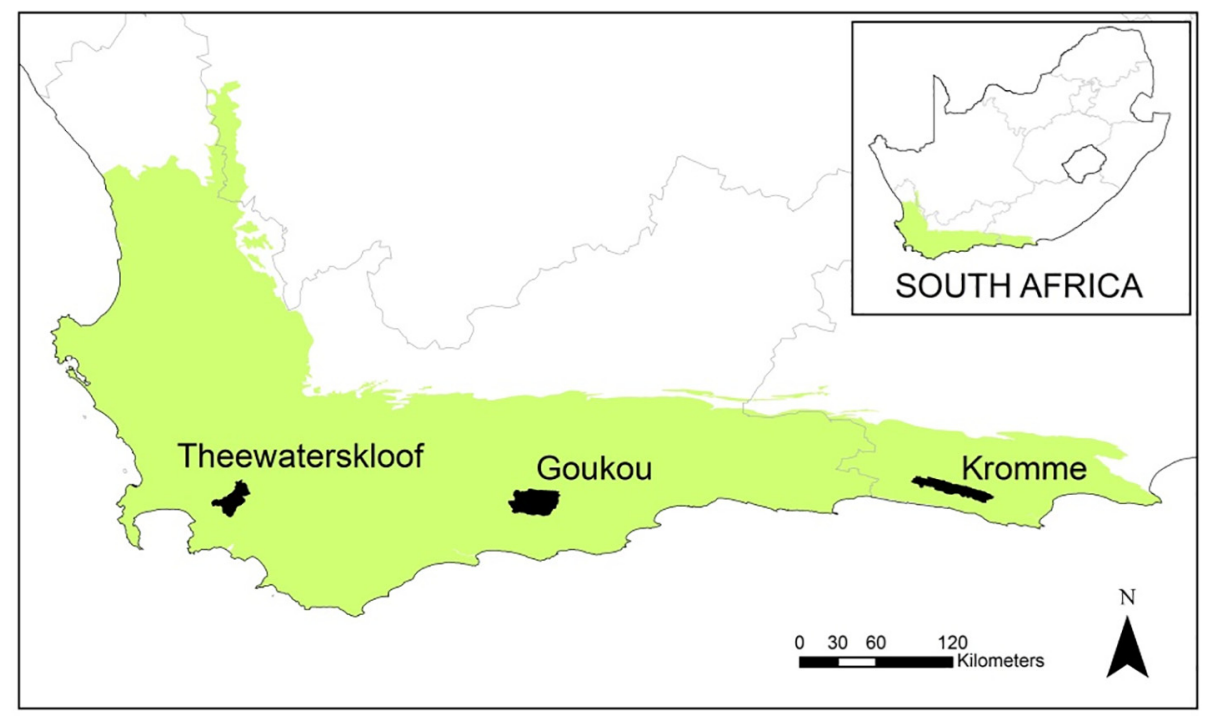

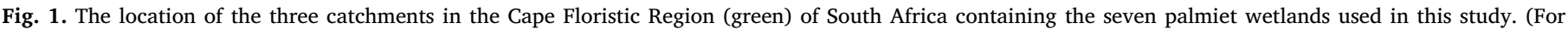
interpretation of the references to colour in this figure legend, the reader is referred to the web version of this article.)

Peatlands are rare in South Africa and are classified as wetlands with organic soils constituting an average organic carbon content of $10 \%$ occurring within a depth of at least $20 \mathrm{~cm}$ (Job and Ellery, 2013). Peatlands comprise different plant communities according to which peatland region they occur in, characterized by various dominant species which determine the characteristics of the peat (Job and Ellery, 2013). To date, eleven peatland regions have been defined in South Africa (Marneweck et al., 2001). One type of South African peatland is dominated by a unique plant species called palmiet, Prionium serratum, which is endemic to southern Africa. Palmiet is noted to be a remarkable species and is hypothesized to be an ecosystem engineer; species that significantly modify their environment in their favour (Sieben, 2012). Due to its deep, extensive rooting structure and clonal nature, it is thought to have stabilized river valleys within the Cape Floristic Region, turning them into unchannelled valley-bottom wetlands and allowing the formation of peat beds (Job, 2014). Due to this structure and their position in the landscape, palmiet wetlands are thought to provide valuable ecosystem services (Rebelo et al., 2015). Their restricted size and distribution, their peat beds and the threats they face in terms of habitat destruction have contributed to their importance (Gründling and Grobler, 2005; Rebelo et al., 2015).

Most palmiet wetlands occur on land that is privately owned (Rebelo et al., 2017). The current economic system incentivizes farm owners to optimize food production, which provides them individual economic benefits, and does little to reward protection of natural resources that would ensure long-term provision of multiple ecosystem services to society at large (Gull, 2012). Palmiet peat-beds have rich soils, favourable for agriculture. However, using the wetland for agriculture is not compatible with other ecosystem service supply, most notably clean water (Gull, 2012; Rebelo, 2012; Rebelo et al., 2015). The associated valley-bottom is also not suitable for agriculture, often being narrow and at high risk of floods (Rebelo et al., 2015). Wetlands that are developed for agriculture eventually become eroded, gullies form, the water table lowers, resulting in marginal (low agricultural productivity) agriculture (Gull, 2012; Rebelo, 2012; Rebelo et al., 2015). Additionally, there is the perception that wetlands are 'wastelands' that show potential for more productive use (Job and Ellery, 2013). This has often led to the mechanical removal of palmiet wetland vegetation (channelization), as this is perceived to 'improve riverflow' (Rebelo, 2012). Therefore, a key issue is the trade-off in ecosystem service provision between these two different land-use scenarios: wetlands or the agriculture that would replace them. Ultimately the resulting wetland degradation is neither beneficial to farmers nor to downstream beneficiaries or stakeholders (Gull, 2012; Rebelo, 2012; Rebelo et al., 2015). Research has shown that only about $50 \%$ of the landowners in the Kromme catchment are able to make ends meet by farming alone (Gull, 2012).

Facing challenges such as the presented case of South African palmiet wetlands, ecosystem services can be a valuable tool to aid policy and decision making, by taking into account the entire suite of ecosystem services that an ecosystem provides (de Groot et al., 2010). The ecosystem services concept is particularly useful when trade-offs between various ecosystem services need to be considered (Seppelt et al., 2011). We aim to compare ecosystem service provision between degraded and pristine palmiet wetlands to understand which ecosystem services are affected by degradation, and to have an overview of the true cost (in terms of effects on ecosystem services) of wetland development, and ultimately degradation. A detailed study of the benefits of agriculture is out of the scope of this study, however we draw from the research of Gull (2012) in the Kromme catchment in this regard. We used a rapid ecosystem service assessment tool (WET-Ecoservices) to evaluate fifteen ecosystem services in degraded and pristine wetlands (Kotze et al., 2007). To validate this technique, we examine the three key ecosystem service complexes in slightly more detail, with the aim to compare these findings with the rapid ecosystem service assessment results.

\section{Methods}

\subsection{Study sites}

Three palmiet wetlands within the Cape Floristic Region of South Africa were selected as study sites (Fig. 1). Despite being situated as much as $470 \mathrm{~km}$ apart, these peatlands are remarkably similar in biochemistry and vegetation community composition (Rebelo, 2017; Rebelo et al., 2017). From each of these wetlands, degraded and pristine parts of the wetland were compared. Relatively wide valley reaches with unchannelled palmiet wetlands were considered to be pristine (least disturbed, or reference) wetland sections. A certain degree of channelization is likely in pristine palmiet basins at points of valley constriction and increased slope (Pulley et al., 2018). Adjacent and geomorphologically similar valley reaches for which it is known that palmiet wetlands have been lost (either through clearing for agriculture, invasion by alien trees, or extensive gully erosion (Rebelo et al., 
2017)) were considered degraded. (Table A1). All wetlands are an important source of water for agriculture, and in addition the Theewaterskloof and Kromme are essential water sources for nearby cities, with large municipal dams downstream (Table A1) (Rebelo, 2012).

\subsection{Rapid assessment: WET-Ecoservices tool}

Fifteen ecosystem services were assessed using the rapid WETEcoservices tool (Kotze et al., 2007) (Table A2). The purpose of the WET-Ecoservices tool is to provide quick ecosystem service assessments of South African wetlands for decision makers, government, planners, consultants and educators. The authors acknowledge that this rapid assessment is not a substitute for a more thorough multi-disciplinary assessment. It is also not a quantitative method. The basis of this tool is the hydro-geomorphic type that each wetland belongs to (e.g. seep, valley-bottom, floodplain, depression) (Kotze et al., 2007). Thus a first step is to identify this hydro-geomorphic type(s) for the wetland in question. Palmiet wetlands tend to be predominantly unchannelled in their pristine state, and become highly channelized (or the alluvium is entirely lost) through gully erosion with degradation, changing hydrogeomorphic unit (Table A1). Users then score characteristics of the 15 ecosystem services from 0 to 4 based on questionnaires that have been developed for each ecosystem service for these South African wetlands (Table A2). Scores are based on field observations or measurements, calculations and information from literature, databases and expert knowledge. A score of 4 would be the highest possible ecosystem service provision, whereas 0 suggests that the wetland is entirely incapable of providing the ecosystem service in question. The tool avoids complicated weighting systems, and instead uses averages to obtain overall comparable ratings.

Provisioning and cultural ecosystem services (direct benefits) are assessed by 'noteworthiness', different aspects considered for different services (see Table A2), while regulating ecosystem services are scored both for 'effectiveness' as well as 'opportunities for improvement', and these two categories are averaged (Kotze et al., 2007). 'Opportunities for improvement' of ecosystem service provision is rated by the realized importance/value of the benefit, (i.e. for the ecosystem service flood attenuation: extent of floodable property downstream), as well as fixed capacity of the catchment (i.e. rainfall intensity, average slope) and other variable factors (i.e. land-use, runoff potential of soils) which could potentially be restored or improved. Confidence for each characteristic is also assessed on a scale of 1-4 (1 being low confidence and 4 , very high confidence). Wetland size is cited to impact certain ecosystem services (positively related), such as flood attenuation, sediment trapping, nutrient and toxicant assimilation, erosion control, carbon storage and food provision. However, in our case, the degraded parts (hydro-geomorphic units) of the study wetlands tended to be larger than pristine parts (Table A1), and therefore it would only have the potential to over-estimate ecosystem service provision of degraded wetlands, not that of pristine wetlands, yielding more conservative comparisons. Overall threats (potential detrimental impact on ecosystem service provision) and future opportunities (enhancing the effectiveness of the hydro-geomorphic unit, or increasing the direct use of a wetland) are also scored for each wetland site. The rationale of this study is to compare the performance of the WET-Ecoservices tool in terms of relative rankings between the different sites with the relative differences in field measurements (Section 2.3).

\subsection{Quantified wetland ecosystem services}

We also estimated components of the three wetland ecosystem service complexes cited as important by Moor et al. (2017) in this study.

\subsubsection{Carbon sequestration}

Carbon sequestration was estimated based on the long-term peat accumulation rates (mm. $\mathrm{a}^{-1}$ ) measured in other studies. In a study on 
palmiet wetlands in the Goukou, peat at $4 \mathrm{~m}$ deep was estimated to be $5050 \pm 30$ years old based on results of carbon dating (Job, 2014). In a study done on the Kromme palmiet wetlands, peat, at $4.05 \mathrm{~m}$ depth, was estimated to be $5620 \pm 70$ years old (Nsor, 2007). This yields long-term peat accumulation rates of between 0.79 and $0.72 \mathrm{~mm} \cdot \mathrm{a}^{-1}$ respectively. These long-term rates of peat accumulation are slow relative to other peatlands globally, e.g. $2.5-11 \mathrm{~mm} \cdot \mathrm{a}^{-1}$ in the subtropical Everglades of Florida (Reddy et al., 1993), and 1.4-2.1 mm.a ${ }^{-1}$ in the high-altitude Andean peatlands of Bolivia (Hribljan et al., 2015), but comparable to other South African studies (Nsor, 2007). No carbon dating has been done on the Theewaterskloof wetland peat, and therefore the full range of accumulation rates estimated for the other two sites was applied $\left(0.71-0.80 \mathrm{~mm}^{-\mathrm{a}^{-1}}\right)$. Peat accumulation (g.m $\mathrm{m}^{-2} \cdot \mathrm{a}^{-1}$ ) was calculated by multiplying the accumulation rates $\left(\mathrm{mm} \cdot \mathrm{a}^{-1}\right)$ by soil bulk density (g. $\left.\mathrm{cm}^{-3}\right)$ for each wetland site (Table 1$)$. Bulk density, soil organic matter (\%) and total carbon (\%) were averaged from field measurements taken in 2014 and 2015 (Rebelo, 2017). Carbon Sequestration ( $\mathrm{g} \cdot \mathrm{m}^{-2} \cdot \mathrm{a}^{-1}$ ) was calculated by multiplying peat accumulation by the averaged \% carbon measured for the wetland (Table 1). Organic matter accumulation ( $\mathrm{g} \cdot \mathrm{m}^{-2} \cdot \mathrm{a}^{-1}$ ) was calculated in the same way, but using \% organic matter (Table 1). Finally, carbon storage $\left(\mathrm{t}^{-\mathrm{a}^{-1}}\right)$ was calculated by multiplying carbon sequestration by the area of the wetland in question.

Uncertainty was estimated for all parameters by using the uncertainty in the dating of the peatlands, yielding uncertainties of $0.71-0.80 \mathrm{~mm}^{-\mathrm{a}^{-1}}$ for the Theewaterskloof wetland, $0.79-0.80 \mathrm{~mm} . \mathrm{a}^{-1}$ for the Goukou and $0.71-0.73 \mathrm{~mm} \cdot \mathrm{a}^{-1}$ for the Kromme (Table 1). Within degraded wetlands, peat accumulation and its uncertainty were estimated for remaining patches of wetland. In addition peat loss and its uncertainty for parts of the degraded wetlands that have been entirely eroded or drained was also calculated, as well as the tonnes of stored carbon that would be released if all the pristine wetlands were to degrade following a similar pattern to the degraded ones (Table 2). These calculations assume that carbon dioxide is released to the atmosphere as a result of decomposition due to oxidation whilst drying out at the site. This is a reasonable assumption according to research by Rebelo (2017) which shows that soil carbon content significantly declines following degradation. During flood events, the alluvium may be washed downstream, however in the case of the Theewaterskloof and the Kromme, this sediment would end up in the dams downstream (Rebelo et al., 2015). Another assumption is the linear relationship of peat accumulation with time. It is likely that peat accumulation has declined with time, and therefore these values presented in this research are likely to be upper estimates. This study investigates carbon sequestration due to peat accumulation only, not storage in vegetation nor mineral soils.

\subsubsection{Water quality regulation}

Water quality regulation is a complex ecosystem service; and whether certain nutrients or pollutants are taken up depends on the properties of the particular solute or sediment itself, the wetland, the season, and other conditions (Rebelo, 2017). One simple way to estimate wetland water quality regulation, is to estimate the nitrogen and phosphorus uptake rates across a stretch of wetland using opportunistic sampling locations (preferential flow paths through the wetlands, or gullies). Mean nitrogen and phosphorus uptake were estimated, as well as efficiency (\%) in degraded and pristine sections of these three palmiet wetlands (Rebelo et al., 2018; Rebelo, 2017; Table 3). Nutrient uptake efficiency was calculated by taking the percentage of the amount of nutrients leaving the wetland from the amount entering the wetland. These estimates have high uncertainty, as (1) they are limited by the level of pollution the system was experiencing at the time of sampling (thus true capacity could be underestimated), (2) uptake rates may change over time, eventually showing saturation and decreased uptake capacity with prolonged eutrophication (Verhoeven et al., 2006), and (3) it is only one measurement in time (Fisher and Acreman, 2004). Estimates of mean total phosphorus and nitrogen uptake by degraded and pristine sections of palmiet wetlands were calculated by multiplying the mean uptake per area by the area of each of the seven study wetlands (Table 4). Uncertainty was calculated using the standard deviation (Table 3) to obtain an upper estimate of nutrient uptake for pristine sites (Table 4). The lower estimate was set as 0 , as no pristine wetlands were shown to act as sources of nutrients. For degraded wetlands both the upper and lower estimates were taken from the standard deviation (Table 4).

\subsubsection{Flood attenuation}

We estimated the flood attenuation ability of palmiet wetlands by considering the relationship between daily rainfall and riverflow for extreme rainfall events (defined as the 20 largest individual rainfall events in each of five decades from 1950 to 2000) and resultant stormflow in the Kromme catchment over 50 years (Rebelo et al., 2015). The flashier the system is (poor flood attenuation), the steeper the gradient of the relationship between riverflow and rainfall. For the purposes of this indicator, from observations of 50 years of data (Rebelo et al., 2015), we assume the worst possible flood attenuation for palmiet wetlands is a 1:1 relationship between riverflow and rainfall (maximum gradient of 1 ). Since the relationship itself is a surrogate for 'flashiness', the inverse of this relationship (1-z) expressed as a percentage can be used as an indicator for flood attenuation. We related this relationship to percentage cover of the wetland relative to the valley-floor using historical data from the Kromme River (Rebelo et al., 2015, Table 5). The assumption is that wetland cover would be one of the major factors influencing flood attenuation. We used a sigmoidal curve (nonlinear regression) using the nls() function in the Stats Package in $r$ to model the relationship for the Kromme wetland (Bates and Chambers, 1992), which produced a very good fit ( $p<0.01)$. The model $(y=0.97 /(1+\exp ((0.25-x) / 0.04)$, where $y$ is the flood

Table 2

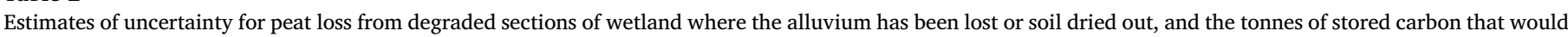
be released if all the pristine wetlands were to degrade following a similar pattern to the degraded ones (Job, 2014; Kotze, 2015; Nsor, 2007).

\begin{tabular}{|c|c|c|c|c|c|c|c|c|c|c|c|}
\hline \multirow[t]{2}{*}{ Wetland } & \multirow[t]{2}{*}{ State } & \multirow[t]{2}{*}{$\begin{array}{l}\text { Wetland Depth } \\
\text { (m) }\end{array}$} & \multirow{2}{*}{$\begin{array}{l}\begin{array}{l}\text { Extent Lost } \\
\text { (or potentially) }\end{array} \\
\left(\mathrm{km}^{2}\right)\end{array}$} & \multicolumn{3}{|l|}{$\begin{array}{l}\text { Peat Loss } \\
\left(\mathrm{m}^{3}\right)\end{array}$} & \multirow[t]{2}{*}{$\begin{array}{l}\text { Soil Bulk Density } \\
\left(\mathrm{g} . \mathrm{cm}^{-3}\right)\end{array}$} & \multirow[t]{2}{*}{$\begin{array}{l}\text { \% Carbon } \\
\text { (mean) }\end{array}$} & \multicolumn{3}{|c|}{$\begin{array}{l}\text { Carbon Loss } \\
\text { (t) }\end{array}$} \\
\hline & & & & lower & mean & upper & & & lower & mean & upper \\
\hline \multirow{2}{*}{ Theewaterskloof } & degraded & $0.5-1.0$ & 0.29 & 145,000 & 217,500 & 290,000 & 0.52 & 8.3 & 6272 & 9408 & 12,544 \\
\hline & pristine & & 0.6 & 300,000 & 450,000 & 600,000 & 0.32 & 12.9 & 12,482 & 18,723 & 24,965 \\
\hline \multirow[t]{3}{*}{ Goukou } & degraded & $3.0-10.0$ & 0.33 & 990,000 & $2,145,000$ & $3,300,000$ & 1.10 & 1.8 & 19,455 & 42,153 & 64,850 \\
\hline & pristine & & 0.31 & 930,000 & $2,015,000$ & $3,100,000$ & 0.28 & 16.4 & 43,091 & 93,363 & 143,636 \\
\hline & pristine & & 0.52 & $1,560,000$ & $3,380,000$ & $5,200,000$ & 0.31 & 16.5 & 80,006 & 173,346 & 266,686 \\
\hline \multirow[t]{2}{*}{ Kromme } & degraded & $0.5-2.8$ & 0.62 & 310,000 & $1,023,000$ & $1,736,000$ & 1.18 & 1.0 & 3746 & 12,363 & 20,980 \\
\hline & pristine & & 0.6 & 300,000 & 990,000 & $1,680,000$ & 0.37 & 8.0 & 8951 & 29,540 & 50,128 \\
\hline Total & & & & $4,535,000$ & $10,220,500$ & $15,906,000$ & & & 174,004 & 378,897 & 583,789 \\
\hline
\end{tabular}


Table 3

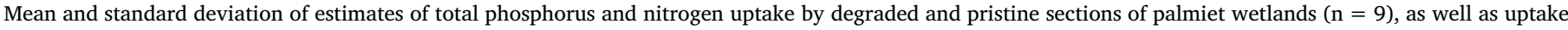
efficiency as a percentage. Negative values indicate nutrient release from the system.

\begin{tabular}{|c|c|c|c|c|c|c|}
\hline & \multicolumn{3}{|c|}{$\begin{array}{l}\text { Total } \mathrm{P} \text { uptake per area } \\
\left(\mathrm{mg} \cdot \mathrm{km}^{-2} \cdot \mathrm{s}^{-1}\right)\end{array}$} & \multicolumn{3}{|c|}{$\begin{array}{l}\text { Kjeldahl N uptake per area } \\
\left(\mathrm{mg} \cdot \mathrm{km}^{-2} \cdot \mathrm{s}^{-1}\right)\end{array}$} \\
\hline & Mean & Standard deviation & Uptake efficiency (\%) & Mean & Standard deviation & Uptake efficiency (\%) \\
\hline Pristine & 216 & 432.6 & $55 \pm 33.0$ & 712 & 1409.0 & $59 \pm 26.4$ \\
\hline Degraded & -159 & 553.7 & $-1120 \pm 1547.8$ & -815 & 2052.3 & $-1284 \pm 1432.6$ \\
\hline
\end{tabular}

attenuation index, and $\mathrm{x}$ is the percentage cover of wetland relative to the valley floor, was then applied to the area of other wetlands relative to the valley bottom of their catchment to estimate respective flood reduction (Table 6).

Uncertainty was quantified overall from the R-squared values for the relationship between riverflow and rainfall (Rebelo et al., 2015, Table 5). The values for the years investigated (Table 5) were averaged, giving a relative uncertainty of $45.97 \%$. This was applied to each estimate to give an upper and lower bound of uncertainty for each flood retention value. This method is over-simplified, as there are more factors contributing to the attenuation of floods than simply the area of wetland in a catchment. Examples of these are geomorphological considerations such as the slope of the catchment, the width of the valleyfloor, the connectivity with groundwater, the depth of the peat and the quality of the wetland itself, as well as ecological considerations: the vegetation cover on the watersheds and biomass of the wetland vegetation.

\section{Results}

According to the rapid ecosystem service assessment, pristine palmiet wetlands provided a greater suite of ecosystem services compared to degraded ones (Fig. 2). Specifically, pristine wetlands scored higher for water-related ecosystem service provision as well as carbon storage, compared to degraded ones. Degraded wetlands consistently scored highly for maintenance of biodiversity. Cultural significance scored low for all palmiet wetlands, whether degraded or pristine. Both Kromme wetlands (degraded and pristine) provided the greatest suite of ecosystem services compared to the other wetlands, Theewaterskloof wetlands scoring the lowest overall. Theewaterskloof differed from the other two catchments in that it currently has no agriculture, therefore provides no cultivated food. The pristine Theewaterskloof wetland provided more regulating ecosystem services, including carbon storage and erosion control, whereas the degraded wetland (gully erosion and invasive alien plants) scored higher for 'water supply for human use'.

The pristine Goukou wetlands provided a similar suite of ecosystem services (high regulating ecosystem services provision, moderate provisioning ecosystem services). The degraded Goukou wetland (gully erosion, invasive alien plants and agriculture) scored lowest for carbon storage as well as tourism and recreation. The pristine Kromme wetland
Table 5

Relating area of wetland relative to the valley floor (1330.8 ha) to the observed reduction in flooding. Reduction in flooding was estimated using the relationship between rainfall and riverflow for extreme rainfall events and resultant stormflow in the Kromme catchment over 50 years (Rebelo et al., 2015). This relationship between riverflow and runoff was expressed as a percentage using the worst case scenario extrapolated from the data: $0 \%$ wetland cover with a resultant gradient of 1 to get a 'flashiness index'. This index was then inverted $(100-\mathrm{z})$ to determine the flood attenuation index (\%).

\begin{tabular}{llll}
\hline & $\begin{array}{l}\text { Estimated area of palmiet } \\
\text { wetland (ha) }\end{array}$ & $\begin{array}{l}\text { Wetland: valley- } \\
\text { bottom (\%) }\end{array}$ & $\begin{array}{l}\text { Reduction in flood } \\
(\%)\end{array}$ \\
\hline 1950 's & 668.58 & 50.24 & 95 \\
1960 's & 381.34 & 28.66 & 67 \\
1980 's & 241.43 & 18.14 & 14 \\
2000 's & 209.03 & 15.71 & 34 \\
\hline
\end{tabular}

Table 6

Estimates of uncertainty for flood attenuation: mean values as well as upper and lower estimates are given based on uncertainty in the fit of the relationship between rainfall and runoff.

\begin{tabular}{llllllll}
\hline Wetland & State & Extent & $\begin{array}{l}\text { \% of valley } \\
\text { bottom }\end{array}$ & \multicolumn{2}{l}{ \% flood reduction } \\
\cline { 5 - 7 } & & $\left(\mathrm{km}^{2}\right)$ & & Lower & Mean & Upper \\
\hline \multirow{2}{*}{ Theewaterskloof } & $\begin{array}{l}\text { degraded } \\
\text { pristine }\end{array}$ & 0.09 & 17 & 6 & 12 & 17 \\
Goukou & degraded & 0.60 & 100 & 14 & 52 & 97 & 100 \\
& pristine & 0.31 & 100 & 3 & 6 & 8 \\
Kromme & pristine & 0.52 & 100 & 52 & 97 & 100 \\
& degraded & 0.06 & 4 & 52 & 97 & 100 \\
& pristine & 0.60 & 100 & 0 & 1 & 1 \\
& & & & 52 & 97 & 10 \\
\hline
\end{tabular}

provided higher levels of regulating ecosystem services (particularly streamflow regulation, erosion control and carbon storage) and some provisioning ecosystem services (water supply for human use) compared to the degraded wetland (severe gully erosion, invasive alien plants and agriculture). In terms of risk of potential threats (Table A3), the degraded Theewaterskloof and both Kromme wetlands scored the highest. Degraded wetlands had the highest scores for opportunities for improvement of ecosystem service provision, which tended to increase

Table 4

Estimates of total phosphorus and nitrogen uptake by palmiet wetlands including uncertainty (upper and lower limits). Extent indicates the area of wetland, regardless of condition or amount of peat remaining.

\begin{tabular}{|c|c|c|c|c|c|c|c|c|}
\hline \multirow[t]{2}{*}{ Wetland } & \multirow[t]{2}{*}{ State } & \multirow{2}{*}{$\begin{array}{l}\text { Extent } \\
\left(\mathrm{km}^{2}\right)\end{array}$} & \multicolumn{3}{|c|}{$\mathrm{N}$ uptake (mg.s $\left.{ }^{-1}\right)$} & \multicolumn{3}{|c|}{ P uptake (mg.s ${ }^{-1}$ ) } \\
\hline & & & Lower & Mean & Upper & Lower & Mean & Upper \\
\hline \multirow[t]{2}{*}{ Theewaterskloof } & degraded & 0.38 & -1090 & -310 & 470 & -271 & -61 & 150 \\
\hline & pristine & 0.60 & 0.00 & 427 & 1273 & 0.00 & 129 & 389 \\
\hline \multirow[t]{3}{*}{ Goukou } & degraded & 0.59 & -1692 & -481 & 730 & -421 & -94 & 233 \\
\hline & pristine & 0.31 & 0.00 & 221 & 658 & 0.00 & 67 & 201 \\
\hline & pristine & 0.52 & 0.00 & 370 & 1103 & 0.00 & 112 & 337 \\
\hline \multirow[t]{2}{*}{ Kromme } & degraded & 0.68 & -1950 & -554 & 842 & -485 & -108 & 268 \\
\hline & pristine & 0.60 & 0.00 & 427 & 1273 & 0.00 & 129 & 389 \\
\hline
\end{tabular}




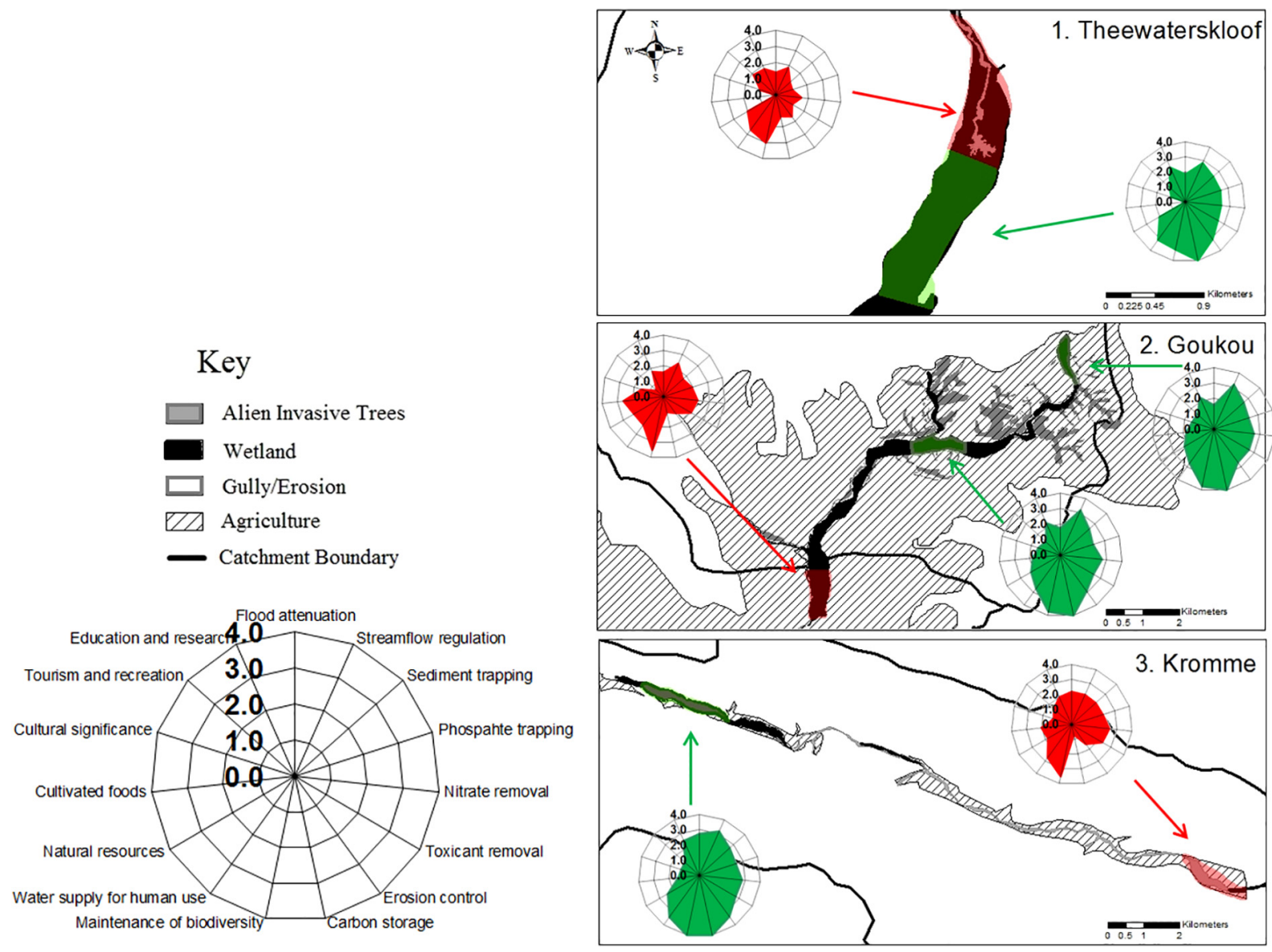

Fig. 2. Results of ecosystem service provision for three South African palmiet wetlands displayed on radar charts. The 15 ecosystem services are scored from 0 to 4 ; red charts indicate degraded wetlands and green pristine. The extent of each wetland section analysed using WET-EcoServices is indicated in red (degraded) and green (pristine). For location of catchments in South Africa see Fig. 1. See Fig. A1 for scores for each ecosystem service. (For interpretation of the references to colour in this figure legend, the reader is referred to the web version of this article.)

their overall ecosystem services scores (Table A3).

Long-term rates of carbon sequestration of wetland fragments from 6 to 60 ha in size are estimated at between 9 and $41 \mathrm{~g} \cdot \mathrm{m}^{-2} \cdot \mathrm{a}^{-1}$ (Table 7), though it will probably be lower as it is based on the longterm average which is likely not to be linearly related to time. Observations in this study suggested that degraded wetland sites tend to be net exporters of sediment (and therefore peat and carbon) due to extensive erosion. To use the example of the gully formed in the degraded Theewaterskloof wetland (Rebelo et al., 2017), which is $15618.4 \mathrm{~m}^{3}$ in size, formed over 10 years, could imply a loss of $1562 \mathrm{~m}^{3}$ alluvium per annum (an estimated $204 \mathrm{~m}^{3}$ of carbon, but possibly less since it has been shown that not all the alluvium is peat (Kotze, 2015)). From the degraded wetlands, around $3385500 \mathrm{~m}^{3}$ of alluvium has been lost, translating to an average of $441800 \mathrm{~m}^{3}$ carbon (Table 2). Not

Table 7

A comparison of estimated ecosystem service values as a function of wetland area $\left(\mathrm{km}^{2}\right)$ and scores from the WET-Ecoservices rapid assessment for three key wetland ecosystem service complexes. Carbon sequestration is given as $\mathrm{mm}$ peat formation per annum based on an accumulation rate of $0.76 \mathrm{~mm} \cdot \mathrm{a}^{-1}$. Water purification is based on nutrient uptake rates of $\mathrm{N}$ and $\mathrm{P}$ respectively. Water regulation is given as the reduction of floods compared to the worst case scenario (\%), based on the percentage of the valley bottom occupied by the wetland. Floods are defined as extreme rainfall events and their resultant stormflow. Details and uncertainty estimates are given in the Methods. Theew: Theewaterskloof, D: degraded, P: pristine.

\begin{tabular}{|c|c|c|c|c|c|c|c|c|c|c|}
\hline \multirow[t]{2}{*}{ Wetland } & \multirow[t]{2}{*}{ State } & \multirow[t]{2}{*}{ Extent $\left(\mathrm{km}^{2}\right)$} & \multicolumn{3}{|c|}{ Carbon sequestration } & \multicolumn{3}{|c|}{$\begin{array}{l}\text { Water quality } \\
\text { regulation }\end{array}$} & \multicolumn{2}{|c|}{$\begin{array}{l}\text { Flood } \\
\text { attenuation }\end{array}$} \\
\hline & & & $\begin{array}{l}\text { C Seq. Rate } \\
\left(\text { g.m } \mathrm{m}^{-2} \cdot \mathrm{a}^{-1}\right)\end{array}$ & $\begin{array}{l}\text { C Storage } \\
\left(\mathrm{t} . \mathrm{a}^{-1}\right)\end{array}$ & Score & $\begin{array}{l}\text { N Uptake } \\
\left(\mathrm{mg} . \mathrm{s}^{-1}\right)\end{array}$ & $\begin{array}{l}\text { P Uptake } \\
\left(\text { mg.s }^{-1}\right)\end{array}$ & Score & $\begin{array}{l}\text { Measured } \\
(\%)\end{array}$ & Score \\
\hline \multirow[t]{2}{*}{ Theewaterskloof } & $\mathrm{D}$ & 0.09 & 33 & 3 & 1.3 & -310 & -61 & 1.3 & 12 & 1.7 \\
\hline & $\mathrm{P}$ & 0.60 & 31 & 19 & 4.0 & 427 & 129 & 2.4 & 97 & 1.8 \\
\hline \multirow[t]{3}{*}{ Goukou } & $\mathrm{D}$ & 0.26 & 16 & 4 & 1.0 & -481 & -94 & 2.2 & 6 & 1.6 \\
\hline & $\mathrm{P}$ & 0.31 & 37 & 11 & 4.0 & 221 & 67 & 2.4 & 97 & 1.6 \\
\hline & $\mathrm{P}$ & 0.52 & 41 & 21 & 4.0 & 370 & 112 & 2.5 & 97 & 1.4 \\
\hline \multirow[t]{2}{*}{ Kromme } & $\mathrm{D}$ & 0.06 & 9 & 1 & 0.7 & -554 & -108 & 2.5 & 1 & 2.3 \\
\hline & $\mathrm{P}$ & 0.60 & 21 & 13 & 4.0 & 427 & 129 & 2.6 & 97 & 2.7 \\
\hline Mean Degraded & & 0.10 & 19 & 3 & 0.75 & -336 & -66 & 1.50 & 6 & 1.40 \\
\hline Mean Pristine & & 0.51 & 33 & 16 & 4.00 & 361 & 109 & 2.48 & 97 & 1.88 \\
\hline
\end{tabular}


considering the emissions from gully erosion, pristine wetlands considered in this study store 5 times more carbon per year relative to degraded wetlands. If the pristine wetlands were lost to erosion, this would represent a loss of between 17 404-583 789 tonnes of carbon (Table 2, see also Tables A4 and A5 for results of ecosystem service loss if pristine wetlands became degraded, and estimates of what ecosystem services would have been provided if the degraded wetlands had not been lost). The rapid assessment tends to score degraded palmiet wetlands as a 1 and pristine ones as a 4 for carbon storage.

Pristine wetlands had nitrogen and phosphorus uptake rates of 221 to $427 \mathrm{mg} . \mathrm{s}^{-1}$ and 67 to $129 \mathrm{mg} . \mathrm{s}^{-1}$ respectively (Table 7). Degraded wetlands appeared to act as a source of nutrients. Conversely, the rapid assessment yielded very similar scores for water quality regulation for pristine and degraded wetlands. Estimates of the ecosystem service flood attenuation suggest that pristine wetlands provide about 16 times higher flood attenuation compared to degraded ones (Table 7). Again, the rapid assessment tended to score flood attenuation very similarly for degraded and pristine wetlands.

If the $16.79 \mathrm{~km}^{2}$ of major remaining palmiet wetlands in the Cape Floristic Region identified in Rebelo et al. (2017) are lost to channel erosion or other degradation, it would represent a total estimated loss

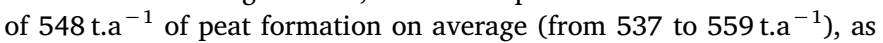
well as the release of thousands of years' worth of stored carbon into the atmosphere (estimated 5000-6000 years (Job, 2014; Nsor, 2007, Table 8)). An estimated water purification capacity of roughly $10 \mathrm{~g}$ of nitrogen $\left(222 \mathrm{~kg} \mathrm{ha}^{-1} \cdot \mathrm{a}^{-1}\right)$ and $3 \mathrm{~g}$ phosphorus per second ( 67 kg.ha ${ }^{-1} \cdot \mathrm{a}^{-1}$ ) would be lost with damage to this ecological infrastructure. Additionally, nutrient uptake efficiencies are estimated to be $55 \pm 33.0 \%$ for phosphorus, and $59 \pm 26.4 \%$ for nitrogen (Table 3 ). Finally, a loss of these palmiet wetlands would represent a loss of an estimated $61 \%$ flood reduction capacity overall (1-97\%). This flood attenuation capacity represents significant protection for downstream agriculture, infrastructure and safety to people (Rebelo, 2012).

\section{Discussion}

An important trade-off appears to exist between the potential food provision of these wetlands and water-related ecosystem services, such as water provision, purification, flood attenuation, as well as with carbon storage. This is evidenced by the fact that pristine wetlands score higher for water-related ecosystem services and carbon storage, and wetlands degraded by agriculture tend to score lower. Interestingly, degraded wetlands only score slightly higher for food provision (cultivated foods) than pristine wetlands. This is because this ecosystem service is scored not only on the total number of crops cultivated in the hydro-geomorphic unit, but also takes into account the opportunity for supply, with an emphasis on supplying impoverished communities (location of hydro-geomorphic unit in rural communal area, level of poverty, number of households depending on crops, and substitutability of the crops). However commercial cultivation and grazing takes place in the wetlands of the Goukou and Kromme, with little subsistence farming or none at all (Gull, 2012). Commercial agriculture takes place in these wetlands despite them being listed as South African Heritage Resources Agency sites (having heritage value based on the presence of paleontological sites, archeological sites, battle fields, meteorite sites, graves or burial grounds).

Agriculture on the valley floor is at risk of high energy floods characteristic of this wetland type (Rebelo et al., 2015). This leads to marginal agriculture, except where extreme, and illegal, river engineering is undertaken on the valley bottom (Rebelo, 2012). As an example: canalization, dredging and the building of berms has been done in the Kromme wetland to protect fruit orchards within the last 10 years (Rebelo, 2012). From the results, it seems that this type of wetland degradation, the profit of which benefits one landowner in the short-term, can be expected to affect water-related ecosystem services for landowners downstream, as well as society at large. To continue with this specific example from the Kromme, the degradation is likely to affect landowners downstream (increased risk of flooding, increased sedimentation, a decrease in water quality), the population of the city Port Elizabeth (decreased water supply in the dry season, increased expense for purifying water, siltation of the Churchill Dam), as well as South Africa at large (increased $\mathrm{CO}_{2}$ release and loss of ecological infrastructure capable of sequestering carbon). Other studies have noted this loss of ecosystem service provision with loss of wetland integrity (McLaughlin and Cohen, 2013; Zedler and Kercher, 2004).

The reason that degraded wetlands scored highly for maintenance of biodiversity on the rapid assessment was that degraded wetlands those with cultivation - provide habitats for International Union for Conservation of Nature listed species, such as the blue crane (Anthropoides paradiseus). However, the Kromme wetland in particular is also known to be home to endangered species of redfin fish, endemic to that catchment, whereas blue cranes occur on many farmlands. This is not taken into account in the rapid assessment. Additionally, scores for maintenance of biodiversity are assessed based on 'opportunity' (i.e. alteration of ecological regimes, loss of indigenous vegetation, invasion by alien species), which reduces the difference between the score of degraded and pristine wetlands. Degraded wetlands also have a high number of alien plant species, the most damaging of which are invasive, such as black wattle (Acacia mearnsii), poplar (Populus sp.) and bramble (Rubus fructicosus) (Rebelo et al., 2015). Unlike many other wetland ecosystems, palmiet wetlands have low cultural significance. In fact, it is likely that degraded palmiet wetlands would hold more cultural significance as people tend to prefer open bodies of water for activities such as swimming. There are historical records of indigenous Khoe-San

Table 8

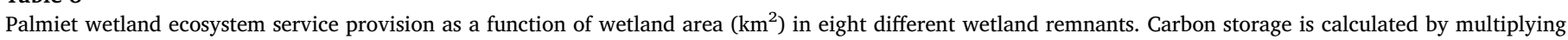

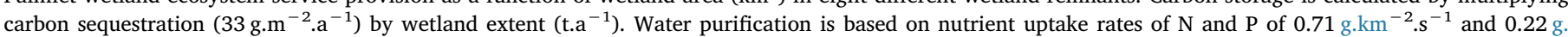

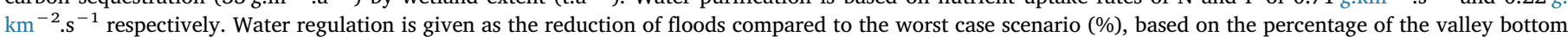
occupied by the wetland. Floods are defined as extreme rainfall events and their resultant stormflow.

\begin{tabular}{|c|c|c|c|c|c|c|c|}
\hline \multirow[t]{2}{*}{ Location } & \multirow[t]{2}{*}{ Catchment } & \multirow{2}{*}{$\begin{array}{l}\text { Extent } \\
\left(\mathrm{km}^{2}\right)\end{array}$} & \multirow{2}{*}{$\begin{array}{l}\text { Carbon storage } \\
\left(\mathrm{t} . \mathrm{a}^{-1}\right)\end{array}$} & \multicolumn{2}{|c|}{ Water purification } & \multicolumn{2}{|l|}{ Water regulation } \\
\hline & & & & $\begin{array}{l}\text { N uptake } \\
\left(\mathrm{mg}^{-s^{-1}}\right)\end{array}$ & $\begin{array}{l}\text { P uptake } \\
\left(\mathrm{mg}^{\left.-s^{-1}\right)}\right.\end{array}$ & $\%$ of valley bottom & $\%$ flood reduction \\
\hline \multirow[t]{2}{*}{ Citrusdal } & \multirow[t]{2}{*}{ Berg Catchment (G) } & 0.27 & 9 & 192 & 58 & 5 & 1 \\
\hline & & 1.26 & 41 & 897 & 272 & 19 & 16 \\
\hline \multirow[t]{2}{*}{ Theewaterskloof } & \multirow[t]{4}{*}{ Breede Catchment $(\mathrm{H})$} & 2.43 & 79 & 1731 & 524 & 54 & 97 \\
\hline & & 2.92 & 95 & 2083 & 630 & 41 & 95 \\
\hline Duivenhoks & & 1.20 & 39 & 852 & 258 & 39 & 94 \\
\hline Goukou & & 5.80 & 189 & 4131 & 1250 & 42 & 96 \\
\hline George & \multirow[t]{3}{*}{ Tsitsikamma Catchment (K) } & 0.82 & 27 & 582 & 176 & 31 & 1 \\
\hline Kromme & & 2.09 & 68 & 1488 & 451 & 16 & 9 \\
\hline Total (Mean) & & 16.79 & 548 & 11,955 & 3618 & 31 & 61 \\
\hline
\end{tabular}


people using pristine palmiet wetlands as spiritual sites, however knowledge on these wetlands beyond their source of food (edible apical meristems of palmiet) has been lost (De Vynck et al., 2016; Skead, 2009).

\subsection{Three ecosystem service complexes}

It must be emphasized that these results are only estimates and they are based on values which have high uncertainty (see methods for details). However, it is certain that the direction of these estimations is correct: that with a loss of wetlands, there would be a loss of ecosystem services (see also Tables A4 and A5). Therefore, these estimations are still useful as they help to highlight the importance of these wetlands. It is clear that losing the remaining palmiet wetland fragments would represent a significant loss of ecological/green infrastructure (or naturally functioning ecosystems that deliver ecosystem services to society (Benedict and McMahon, 2006)).

Water purification estimates compare well with those of other studies, for example uptake rates of $0.13-10 \mathrm{~kg} \mathrm{P} \cdot \mathrm{ha}^{-1} \cdot \mathrm{a}^{-1}$ and $52-337 \mathrm{~kg} \mathrm{~N} \cdot \mathrm{ha}^{-1} \cdot \mathrm{a}^{-1}$ were found in Danish riparian wetlands (Hoffmann et al., 2011), and $2.7 \mathrm{~kg}$ P.ha ${ }^{-1} \cdot \mathrm{a}^{-1}$ and $339 \mathrm{~kg} \mathrm{~N} \cdot \mathrm{ha}^{-1} \cdot \mathrm{a}^{-1}$ in constructed wetlands in Illinois, USA (Hoagland et al., 2001). Restored wetlands in Illinois and Iowa, USA, had uptake efficiencies of $68 \%$ nitrogen and $43 \%$ phosphorus (Woltermade, 2000), and $47 \%$ nitrogen and 29\% phosphorus in constructed wetlands in Illinois (Hoagland et al., 2001). The loss of the water purification ecosystem service in palmiet wetlands could occur in two ways: either through crossing a pollution threshold or through the loss of the wetlands themselves through erosion or removal for agriculture (Rebelo, 2017). Pollution of palmiet wetlands through agricultural runoff will make use of the water purification ability of these wetlands, however this too will have a cost, in terms of declining capacity with use, and impacts on biodiversity (Verhoeven et al., 2006). Carbon sequestration rates also compared well with other studies globally. Undisturbed peatland in Scotland accumulated $0.25 \mathrm{t}^{\mathrm{h} \mathrm{h}^{-1}}$ carbon per year according to 22 months of continuous eddy covariance measurements (Hargreaves et al., 2003). Long-term carbon accumulation rates in Finland, Estonia and Maine (USA) ranged from 4.6 to $85.8 \mathrm{~g} \cdot \mathrm{m}^{-2} \cdot \mathrm{a}^{-1}$ depending on the location, wetland type and age (Page et al., 2004). Reduction of palmiet wetland area combined with degradation in other parts of the catchment (e.g. increased fire return interval on the mountains) has been shown to increase flood response (Rebelo et al., 2015). Historically this has resulted in increased damage, in terms of loss of agriculture (e.g. orchards washing away), damage to infrastructure such as roads and bridges, and even death (Rebelo, 2012).

\subsection{An assessment of the rapid ecosystem services tool}

There is an urgent need for validation of ecosystem service assessments, however these are few and far between (Boerema et al., 2017). The South African WET-Ecoservices tool was useful for rapid assessments of palmiet wetlands, to give an idea of the overall ecosystem service trade-offs and synergies for degraded compared to pristine wetlands. However, when these relative differences between degraded and pristine wetlands were compared with the results of three ecosystem services which had been estimated in more detail, it seemed that the rapid assessment scored degraded wetlands higher than they should. This is particularly evident for the ecosystem service flood attenuation and water purification. The reason for these unrealistically high scores seems to be the fact that 'opportunities for improvement' are included in the final score along with 'effectiveness'. Opportunities for improvements within the pristine wetlands are lower than the degraded wetlands, as they already supply the highest level of ecosystem services they are intrinsically able to provide. The authors do recognize this limitation, and suggest that, where appropriate, both scores should be reported (Kotze et al., 2007). However, upon scrutiny, we decided to leave these scores as an average because we considered the 'opportunities for improvement' to be less about future improvements and more about whether there were beneficiaries for the ecosystem services, and whether there was in fact a need for the ecosystem services at all (Spangenberg et al., 2014). For example, for the ecosystem service 'flood attenuation', the following are listed as opportunities for improvement: average slope of the wetland's catchment, inherent runoff potential of soils in catchment, contribution of catchment land-uses to changing runoff intensity from the natural condition, rainfall intensity and extent of floodable property downstream.

It seems highly appropriate that the demand for the ecosystem service is considered in its scoring (Spangenberg et al., 2014). Rather, it seems that the problem of the scoring lies in its inappropriateness for this particular hydro-geomorphic type: valley-bottom wetlands. It seems better suited to floodplain wetlands. For example, the ecosystem service is scored on: the size of the wetland, the slope, the surface roughness, presence of depressions, frequency of stormflows, sinuosity of the channel and representation of different hydrological zones. These pristine valley-bottom palmiet wetlands do not have channels nor depressions, and most of the other parameters are constant for the catchment. Therefore, degraded wetlands are incorrectly scored similarly to pristine ones. It is recommended that for the valley-bottom hydro-geomorphic unit, different parameters are used for scoring regulating ecosystem services, such as presence of a channel or other erosion, loss of native vegetation due to alien invasion, height/density of the vegetation, width of the valley, amongst others.

\subsection{Implications for decision making}

The WET-Ecoservices tool is particularly useful for rapid appraisals of wetland ecosystem services of most South African hydro-geomorphic units (Sieben et al., 2017). However, for unchannelled valley-bottom wetlands, there appear to be some challenges, especially for water-related ecosystem services, whereby pristine wetlands are underscored. This could present challenges for decision-makers using this tool, who might decide that agriculture is beneficial holistically, because degradation would not appear to affect ecosystem service supply significantly. However, if analyzed in a little more depth, as done in this study, it is possible to understand where the issues lie, and to adapt the tool for this hydro-geomorphic unit accordingly. It is still a valuable way to understand the relevant trade-offs and synergies between ecosystem services. From the results, it is clear that pristine palmiet wetlands provide valuable ecosystem services to society, both to downstream users and society as a whole. Nowadays most planning, management and development decisions regarding the conservation of wetlands are implemented based on economic grounds and the forces at play within the free-market system (Bullock et al., 2011). Therefore, agriculture and wetland conservation will always be in conflict, as farming is a business and farmers need to make a living (van der Valk and Jolly, 1992).

However decision-makers have some strategic decisions to make in terms of land-use planning, in light of the demonstrated conflicts between agriculture and palmiet wetlands ( $\mathrm{Nel}$ et al., 2013). It is clear from our findings that palmiet wetlands provide valuable water-related ecosystem services, but that the agriculture that could replace them is marginal (Gull, 2012). In a water scarce country, this makes a strong case to prioritize these catchments for water-provision, and preferentially focus agricultural activities in catchments where agriculture has higher productivity, faces fewer threats (e.g. floods) and is generally more profitable.

With a decline in governmental support for conservation within and outside protected areas, a greater pressure to create innovative and maintainable solutions for endorsing and financing conservation is needed (Lukey et al., 2017). Biodiversity offsetting and Payments for Ecosystem Services are market-based mechanisms that have the potential for playing a vital role in reaching conservation goals and 
supporting ecosystem health in a more general sense (Blignaut et al., 2010; Lukey et al., 2017; Turpie et al., 2008). The aim of Payments for Ecosystem Services is to remunerate those who are providing ecosystem services as an incentive to protect the system from development, or to restore the system. This involves quantifying ecosystem service provision, and valuing these ecosystem services, and introducing them into the economy (Bullock et al., 2011). Governments may be willing to invest in the protection of ecosystem services that have a tangible (economic) benefit, such as water provision (Tallis et al., 2008). In the case of palmiet wetlands, at least two occur upstream of important water impoundments for large cities (the Kromme for Port Elizabeth and the Theewaterskloof for Stellenbosch and Cape Town). Therefore, there is certainly scope to create an economic argument for the protection of palmiet wetlands through a Payments for Ecosystem Services system. Organizations such as 'Living Lands' in the Kromme aim to restore degraded landscapes to 'living landscapes' through acting as landscape mobilizers, by improving collaboration between the different stakeholders and beneficiaries of these ecosystem services in the landscape (Cowling et al., 2008).

One successful example of this strategy is that of the Catskill Catchment in New York (Postel and Thompson, 2005), where holistic farm planning was developed as an attempt to decrease pollution of the watershed. In this system, farmers were incentivized to pollute less, by having their operational and capital costs of investment into pollution control covered by the city of New York. Through collaboration, cost efficiency was achieved and private as well as social benefits realized. Such a model could be applied in palmiet wetlands, whereby landowners could be variously compensated for either (1) farming sustainably (no till, rainfed irrigation, appropriate grazing densities, natural fire regimes) and maintaining legal buffer strips adjacent to wetlands, (2) not farming in the narrow valley bottoms at all, but continued grazing at appropriate densities on mountain slopes, natural fire regimes, agriculture in the uplands, possibly combined with ecotourism, or (3) transitioning from traditional farming to alternative income streams such as ecotourism, or entering into biodiversity stewardship agreements or adding the land to a nature reserve. This financial investment by municipalities or the private sector, combined with well-managed and gauged water use by landowners, would theoretically result in improved water security, reduced flood damage and an improvement in water quality. In effect it would be maximizing the water-related ecosystem services of these strategic water source areas, as well as providing fringe benefits such as carbon sequestration and habitat biodiversity amongst others. Investing in palmiet wetlands ecological infrastructure could be a viable way for cities downstream of these wetlands to augment their water supply, and decrease costs of water purification.

It is important to note that this is not a 'one-size-fits-all' solution. This strategy is suggested for catchments containing valley-bottom palmiet wetlands because they have been found to provide valuable water-related ecosystem services, with marginal agricultural benefits (Gull, 2012). The production of food and improved food security is critical for South Africa. However we argue that there needs to be greater strategic thought put into whether a catchment is 'farmed' for food or for water, as this is not always compatible, and trade-offs exist (Nel et al., 2013). There may be other catchments where agriculture is highly productive and profitable, not in conflict with a strategic water source area (Nel et al., 2013), where this approach would not be appropriate. However there is a strong argument that for arid countries, like South Africa, agriculture should be strategically limited in less suitable catchments for food production where water ecosystem services are critical. Whether a payments for ecosystem services scheme is appropriate would be up to the beneficiaries to decide (e.g. the cities downstream who depend on the water). If they value the water enough, and are willing to pay to assist landowners in making a shift towards more sustainable methods, there are opportunities for the improvement of water related ecosystem services in these catchments.

\section{Conclusion}

Pristine palmiet wetlands provide valuable ecosystem services to society, which are currently being compromised for marginal private gain. These pristine wetlands sequester between 21 and $41 \mathrm{~g} \cdot \mathrm{m}^{-2}$ of carbon per year, have nitrogen and phosphorus uptake efficiencies of $62-85 \%$ and $16-89 \%$ respectively and provide about 16 times more flood attenuation relative to degraded wetlands. The full impact of degradation on wetland ecosystem services was not entirely captured by the rapid ecosystem service assessment tool: WET-Ecoservices. We suggest some adaptations for the hydro-geomorphic unit: valley-bottom wetlands. Overall these wetlands have high potential for incorporation into a Payments for Ecosystem Services scheme, due to their position above important water impoundments (demand for ecosystem services). We recommend collaboration between private landowners struggling with marginal agriculture, and decision makers in cities dealing with water shortages and debt to ensure the most efficient and judicious use of these palmiet wetland ecosystem services.

AJR conceived the study, AJR, CM performed data analysis, AJR, $\mathrm{CM}$ wrote the manuscript and KJE, PM contributed and edited it.

\section{Acknowledgements}

This work was supported by the Erasmus Mundus Programme (European Commission), the Applied Centre for Climate and Earth System Science (ACCESS), a Consolidoc grant (Stellenbosch University) and GreenMatter, South Africa. Thank you to Byron-Mahieu van der Linde and Timothy De Kleyn for essential assistance in the field and to Dr Erik Franssen of STATUA for assistance with statistical analysis. Research was conducted under permit number: 0052-AAA008-00019 (Cape Nature). Two anonymous reviewers are thanked for improving the manuscript.

\section{Appendix A. Supplementary data}

Supplementary data to this article can be found online at https:// doi.org/10.1016/j.ecolind.2018.12.043.

\section{References}

Bates, D.M., Chambers, J.M., 1992. Nonlinear models. In: Chambers, J.M., Hastie, T.J. (Eds.), Statistical Models. Wadsworth \& Brooks/Cole.

Benedict, M.A., McMahon, E.T., 2006. Green infrastructure: Linking landscapes and communities. Island Press, Washington, D.C.

Blignaut, J., Mander, M., Schulze, R., Horan, M., Dickens, C., Pringle, C., Mavundla, K., Mahlangu, I., Wilson, A., McKenzie, M., McKean, S., 2010. Restoring and managing natural capital towards fostering economic development: evidence from the Drakensberg, South Africa. Ecol. Econ. 69, 1313-1323. https://doi.org/10.1016/j. ecolecon.2010.01.007.

Boerema, A., Rebelo, A.J., Bodi, M.B., Esler, K.J., Meire, P., 2017. Are ecosystem services adequately quantified? J. Appl. Ecol. 54, 358-370. https://doi.org/10.1111/13652664.12696.

Bullock, J.M., Aronson, J., Newton, A.C., Pywell, R.F., Rey-Benayas, J.M., 2011. Restoration of ecosystem services and biodiversity: conflicts and opportunities. Trends Ecol. Evol. 26, 541-549. https://doi.org/10.1016/j.tree.2011.06.011.

Cowan, G., 1995. Wetlands of South Africa. Department of Environmental Affairs and Tourism.

Cowling, R.M., Egoh, B., Knight, A.T., Farrell, P.J.O., Reyers, B., Rouget, M., Roux, D.J. Welz, A., Wilhelm-Rechman, A., 2008. An operational model for mainstreaming ecosystem services for implementation. Proc. Natl. Acad. Sci. U.S.A. 105, 9483-9488.

de Groot, R.S., Alkemade, R., Braat, L., Hein, L., Willemen, L., 2010. Challenges in integrating the concept of ecosystem services and values in landscape planning, management and decision making. Ecol. Complex. 7, 260-272. https://doi.org/10.1016/ j.ecocom.2009.10.006.

De Vynck, J.C., Van Wyk, B.E., Cowling, R.M., 2016. Indigenous edible plant use by contemporary Khoe-San descendants of South Africa's Cape South Coast. South African J. Bot. 102, 60-69. https://doi.org/10.1016/j.sajb.2015.09.002.

Fisher, J., Acreman, M.C., 2004. Wetland nutrient removal: a review of the evidence. Hydrol. Earth Syst. Sci. 8, 673-685. https://doi.org/10.5194/hess-8-673-2004.

Gründling, P.-L., Grobler, R., 2005. Peatlands and Mires of South Africa. Stapfia 35, 379-396.

Gull, K., 2012. Water Supply in the Eastern Cape: An Economic Case Study of Land Rehabilitation in the Kromme River Catchment Masters. University of Cape Town. 
Hargreaves, K.J., Milne, R., Cannell, M.G.R., 2003. Carbon balance of afforested peatland in Scotland. Forestry 76, 299-317.

Hoagland, C.R., Gentry, L.E., David, M.B., Kovacic, D.A., 2001. Plant nutrient uptake and biomass accumulation in a constructed wetland. J. Freshw. Ecol. 16, 527-540. https://doi.org/10.1080/02705060.2001.9663844.

Hoffmann, C.C., Kronvang, B., Audet, J., 2011. Evaluation of nutrient retention in four restored Danish riparian wetlands. Hydrobiologia 674, 5-24. https://doi.org/10. 1007/s10750-011-0734-0.

Hribljan, J.A., Cooper, D.J., Sueltenfuss, J., Wolf, E.C., Heckman, K.A., Lilleskov, E.A., Chimner, R.A., 2015. Carbon storage and long-term rate of accumulation in highaltitude Andean peatlands of Bolivia. Mires Peat 15, 1-14.

Job, N., 2014. Geomorphic Origin and Dynamics of Deep, Peat-Filled, Valley Bottom Wetlands Dominated by Palmiet (Prionium serratum) - A Case Study Based on the Goukou Wetland, Western Cape. Rhodes University, Eastern Cape.

Job, N., Ellery, F., 2013. Policy brief: Halting degradation of Southern Cape peatlands in agricultural landscapes. Pol. Brief Rhodes Univ. 8, 1-8.

Kotze, D.C., 2015. A Survey of Organic Soils in the Upper Riviersonderend Catchment. WWF, South Africa.

Kotze, D.C., Marneweck, G.C., Batchelor, A.L., Lindley, D.S., Collins, N.B., 2007. WETEcoServices: A Technique for Rapidly Assessing Ecosystem Services Supplied by Wetlands. WRC Report No TT 339/08. Pretoria.

Lukey, P., Cumming, T., Paras, S., Kubiszewski, I., Lloyd, S., 2017. Making biodiversity offsets work in South Africa - a governance perspective. Ecosyst. Serv. 27, 281-290. https://doi.org/10.1016/j.ecoser.2017.05.001.

Marneweck, G., Grundling, P.-L., Muller, J., 2001. Defining and Classification of Peat Wetland Eco-Regions in South Africa. Pretoria.

McLaughlin, D.L., Cohen, M.J., 2013. Realizing ecosystem services: wetland hydrologic function along a gradient of ecosystem condition. Ecol. Appl. 23, 1619-1631.

MEA, 2005. Millennium Ecosystem Assessment: Ecosystems and Human Well-Being: Synthesis. Island Press, Washington (DC).

Moor, H., Rydin, H., Hylander, K., Nilsson, M.B., Lindborg, R., Norberg, J., 2017. Towards a trait-based ecology of wetland vegetation. Int. J. Lab. Hematol. 10, 11. https://doi. org/10.1111/ijlh.12426.

Nel, J., Colvin, C., Maitre, D Le, Smith, J., Haines, I., 2013. South Africa's Strategic. Water Source Areas.

Nel, J.L., Driver, A., 2012. South African National Biodiversity Assessment 2011 Technical Report. Volume 2: Freshwater Component. Stellenbosch.

Nsor, A.C., 2007. Plant Community Distribution and Diversity, and Threats to Vegetation of the Kromme River Peat Basins, Eastern Cape Province, South Africa (M.Sc. Thesis). Rhodes University.

Page, S.E., Wûst, R.A.J., Weiss, D., Rieley, J.O., Shotyk, W., Limin, S.H., 2004. A record of Late Pleistocene and Holocene carbon accumulation and climate change from an equatorial peat bog (Kalimantan, Indonesia): implications for past, present and future carbon dynamics. J. Quat. Sci. 19, 625-635. https://doi.org/10.1002/jqs.884.

Postel, S.L., Thompson, B.H., 2005. Watershed protection: capturing the benefits of nature's water supply services. Nat. Resour. Forum 29, 98-108. https://doi.org/10. 1111/j.1477-8947.2005.00119.x.

Pulley, S., Ellery, W.N., Lagesse, J.V., Schlegel, P.K., McNamara, S.J., 2018. Gully erosion as a mechanism for wetland formation: An examination of two contrasting landscapes. L. Degrad. Dev. 1-12. https://doi.org/10.1002/ldr.2972.

Rebelo, A., Emsens, W., Esler, K., Meire, P., 2018. Quantification of water purification in
South African Palmiet Wetlands. Water Sci, Technol In press.

Rebelo, A.J., 2017. Ecosystem Services of Palmiet Wetlands: The Role of Ecosystem Composition \& Function. University of Antwerp.

Rebelo, A.J., 2012. An Ecological and Hydrological Evaluation of the Effects of Restoration on Ecosystem Services in the Kromme River System, South Africa (Masters thesis).

Rebelo, A.J., Le Maitre, D.C., Esler, K.J., Cowling, R.M., 2015. Hydrological responses of a valley-bottom wetland to land-use/land-cover change in a South African catchment: making a case for wetland restoration. Restor. Ecol. 23, 829-841. https://doi.org/10. $1111 /$ rec. 12251.

Rebelo, A.J., Scheunders, P., Esler, K.J., Meire, P., 2017. Detecting, mapping and classifying wetland fragments. Remote Sens. Appl. Soc. Environ. 8, 212-223.

Reddy, K.R., Delaune, R.D., DeBusk, W.F., Koch, M.S., Delaune, R.D., Koch, M.S., 1993. Long-term nutrient accumulation rates in the everglades. Soil Sci. Soc. Am. J. 57, 1147. https://doi.org/10.2136/sssaj1993.03615995005700040044x.

Seppelt, R., Dormann, C.F., Eppink, F.V., Lautenbach, S., Schmidt, S., 2011. A quantitative review of ecosystem service studies: approaches, shortcomings and the road ahead. J. Appl. Ecol. 48, 630-636. https://doi.org/10.1111/j.1365-2664.2010. 01952.x.

Sieben, E.J.J., 2012. Plant functional composition and ecosystem properties: the case of peatlands in South Africa. Plant Ecol. 213, 809-820. https://doi.org/10.1007/ s11258-012-0043-3.

Sieben, E.J.J., Khubeka, S.P., Sithole, S., Job, N.M., Kotze, D.C., 2017. The classification of wetlands: integration of top-down and bottom-up approaches and their significance for ecosystem service determination. Wetl. Ecol. Manage. 1-18. https://doi. org/10.1007/s11273-017-9585-4.

Skead, C., 2009. Historical Plant Incidence in Southern Africa; Strelitzia 24. Pretoria, South Africa.

Spangenberg, J.H., Görg, C., Truong, D.T., Tekken, V., Bustamante, J.V., Settele, J., 2014 Provision of ecosystem services is determined by human agency, not ecosystem functions. Four case studies. Int. J. Biodivers. Sci. Ecosyst. Serv. Manage. 10, 40-53. https://doi.org/10.1080/21513732.2014.884166.

Tallis, H., Ferdaña, Z., Gray, E., 2008. Linking terrestrial and marine conservation planning and threats analysis. Conserv. Biol. 22, 120-130. https://doi.org/10.1111/j. 1523-1739.2007.00861.x.

Turpie, J.K., Marais, C., Blignaut, J.N., 2008. The working for water programme: evolution of a payments for ecosystem services mechanism that addresses both poverty and ecosystem service delivery in South Africa. Ecol. Econ. 65, 788-798. https://doi. org/10.1016/j.ecolecon.2007.12.024.

van der Valk, A.G., Jolly, R.W., 1992. Recommendations for research to develop guidelines for the use of wetlands to control rural nonpoint source pollution. Ecol. Eng. 1, 115-134.

Verhoeven, J.T.A., Arheimer, B., Yin, C., Hefting, M.M., 2006. Regional and global concerns over wetlands and water quality. Trends Ecol. Evol. 21, 96-103. https://doi. org/10.1016/j.tree.2005.11.015.

Woltermade, C.J., 2000. Ability of restored wetlands to reduce nitrogen and phosphorus concentrations in agricultural drainage water. J. Soil Water Conserv. 3, 303-309.

Zedler, J.B., Kercher, S., 2004. Causes and consequences of invasive plants in wetlands: opportunities, opportunists, and outcomes. Crit. Rev. Plant Sci. 23, 431-452. https:// doi.org/10.1080/07352680490514673. 